\title{
The influence of journal publisher characteristics on open access policy trends
}

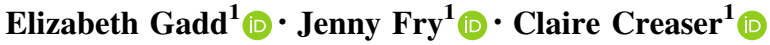

Received: 7 December 2017/Published online: 11 April 2018

(C) The Author(s) 2018

\begin{abstract}
Examines SHERPA/RoMEO publisher open access (OA) policy information for 100 publishers over a 13 year period (2004-2016) to consider whether their size, type or country (UK or US) affected the development of their OA policy over time. A publisher's RoMEO colour code, whether they offered a Gold OA option, and the mean number of restrictions as to when, how and where papers may be self-archived, were all mapped. Kruskal-Wallis tests were run to assess whether the differences between their 2004 and 2016 positions were statistically significant. Finds that the growth of Green and Gold OA policy approaches has not been evenly distributed amongst publishers with some significant differences amongst publishers of different size, types and country (UK and US). Large commercial publishers are more likely to be allocated a RoMEO colour code, but at the same time place a high volume of restrictions as to where and how authors might selfarchive. Small publishers are less likely to have a RoMEO green colour code, but the volume of restrictions they place on self-archiving are minimal. University presses appear not to be engaging with either OA agenda to any considerable degree. UK and US publishers' OA policies appear to be influenced by the national OA policy environment which, considering the global nature of the scholarly journals market, was more pronounced than might have been anticipated.
\end{abstract}

Keywords Open access $\cdot$ Self-archiving $\cdot$ Publishers $\cdot$ Policies

\section{Introduction}

The provision of open access (OA) to the research literature is an important part of the modern scholarly communication landscape, although stakeholders disagree as to the best way of achieving this. Most proponents argue for either Green OA whereby an author 'self-

Elizabeth Gadd

e.a.gadd@lboro.ac.uk

1 Loughborough University, Loughborough, Leicestershire, UK 
archives' their research outputs on the open web subject to their publisher's policy which may or may not impose an embargo period, or Gold open access whereby the author publishes in a Gold OA journal either with or without paying an Article Processing Charge (APC). Recently, however, other variants of OA have emerged. These include Diamond OA (Fuchs and Sandoval 2013) which describes Gold OA journals that do not charge APCs, and Black OA which describes self-archiving a paper in (deliberate or accidental) contravention of a publisher's agreement (Björk 2017). Previous research has shown that Gold OA is growing at a greater rate than Green OA (Archambault et al. 2014); however recent investigations suggest that Black OA is common and may be on the rise (Jamali 2017).

One thing is clear: whilst publishers continue to insist on copyright assignment, and authors comply, it is the publisher who dictates all legal forms of OA. With this in mind, a prior investigation sought to understand how publisher's OA policies had developed over a twelve year period (2004-2015). It found that whilst more publishers were meeting the technical requirements for Green OA, the volume of restrictions on what could be selfarchived, how, where and when had grown 119, 190 and 1000\% respectively, and the proportion of publishers offering a Gold OA option increased $1670 \%$ over the same timeframe (Gadd and Troll Covey 2016). However, the previous study included a range of different publishers of varying sizes, types and geographic locations, and we hypothesize that such demographics have a considerable influence on OA approaches. This study therefore seeks to delve further into the original dataset resulting from the Gadd and Troll Covey (ibid) study, expanded to include data from 2016, to investigate whether a publisher's size, type or country affected the development of its OA policy over time. The specific research questions addressed by this paper are:

Does a publisher's size, type or country affect their Green OA policy as to what, when, how and where papers may be self-archived and the likelihood that they will offer a Gold OA option?

\section{Literature review}

Morris observed in 2007 that "[t]here is surprisingly little hard information about the landscape of peer-reviewed journal publishing" particularly when broken down by demographics. One decade on the situation has changed little, as recently observed by Johnson et al. (2017) with particular regard to the influence of publisher demographics on their OA policies. In the absence of a systematic and comprehensive overview the current state of play has to be gleaned from a variety of different and often dated sources, rather than any comprehensive overview.

\section{Publisher size}

As Ware and Mabe (2015) have noted, journals are not evenly distributed across publishers. They write, "at one end of the scale, $95 \%$ or more publish only one or two journals, while at the other end, the top 100 publish $67 \%$ of all journals. The top 5 publish nearly $35 \%$ of journals, while three publishers (Elsevier, Springer, and Wiley-Blackwell) have well over 2000 journals each". The EU OpenAIRE report (Johnson et al. 2017) found that $50 \%$ of all articles were published by five large publishers (Reed-Elsevier, Springer Nature, 
Wiley-Blackwell, Taylor \& Francis, and Sage). Other studies (Morris 2007; Crow 2005) report similarly skewed distributions although with slightly different proportions.

In terms of the impact of publisher size on OA policy, the series of Association of Learned and Professional Society Publishers (ALPSP)-commissioned studies of society publishers' approaches to online publishing provide some insight. The most recent ALPSP study divided responding publishers into small (0-10 titles), medium (11-99) or large $(100+)$ groupings for analysis (Inger and Gardner 2013). Although they only had a small number of large publisher respondents (15 out of 261) they found that smaller publishers were less likely than medium sized publishers, who in turn were less likely than large publishers, to allow authors to submit either their pre-print or post-print (defined as the author's version of the corrected, accepted manuscript) to an institutional repository. However, small publishers were actually more likely to allow the self-archiving of the publisher PDF than either medium or large publishers. Inger and Gardner (2013:42) speculate that larger publishers may have more to lose in allowing publisher PDFs to be mounted on open access repositories whilst "[s]mall and medium-sized publishers may be happier to take a risk in favour of increased exposure and possible citations."

Inger and Gardner (2013) also perform an interesting trend analysis relating to publishers' changing positions on allowing posting to repositories over time. This shows that as of 2012, smaller publishers had become increasingly permissive with regards to posting to both institutional and subject repositories (see Table 1) whereas larger publishers had become increasingly restrictive. Medium-sized publishers appear less consistent, but were less permissive about posting to institutional repositories and more permissive about subject repositories in 2012 than in 2005.

In terms of Gold OA, a JISC report into Article Processing Charges (APCs) tells us that "a few large publishers capture most of the market share" (Shamash 2016). Pinfield et al's study into the total cost of ownership of scholarly journals concurs that "most APCs were paid to large 'traditional' commercial publishers who also received considerable subscription income" (Pinfield et al. 2015). A blog post by Clarke (2015) regarding the Changing scale of scholarly publication suggests that Gold OA publishing tends to suit large commercial publishers because they have the scale to support the production of a high volume of OA journals at varying levels of quality and the mechanisms to support institutional APC payments. A further influence is the recent growth in so-called megajournals, publishing large volumes of articles on a Gold OA model (Wakeling et al. 2016).

Table 1 After Inger and Gardner (2013). Percentage of publishers allowing posting to institutional and subject repositories over time

\begin{tabular}{llll}
\hline Publishers allowing posting to repository (\%) & 2005 & 2008 & 2012 \\
\hline Institutional & & & \\
Small & 23 & 40 & 58 \\
Medium & 40 & 48 & 30 \\
Large & 67 & 53 & 18 \\
Subject & & & \\
Small & 15 & 18 & 58 \\
Medium & 24 & 18 & 42 \\
Large & 50 & 27 & 29 \\
\hline
\end{tabular}




\section{Publisher type}

There are two main ways of considering publisher type in the literature. Some studies focus on whether a publisher is profit-making (commercial) or not-for-profit (NFP), whilst others categorise them according to whether they are commercial, a university press or a learned society. More recent studies point out the emergence of a new category of professional non-commercial publishers such as Public Library of Science (Laakso and Björk 2012). In 2009, Ware and Mabe estimated that $64 \%$ of all publishers were commercial, whilst $30 \%$ were society publishers, $4 \%$ university presses, and $2 \%$ were other types.

The distinctions, however, are muddied as a result of some learned societies choosing to publish their journals with commercial publishers. Analysis by Crow (2005) and Morris (2007) estimated that $38 \%$ of active refereed journal titles were non-profit, with $45 \%$ being commercial, however a further $17 \%$ were commercially published and society-owned titles. Morris surmised that this showed that approximately $27.5 \%$ of all commercially published journals were society owned and about $30 \%$ of all society-owned titles were published by commercial publishers. An analysis by Baldwin (2004), found that over half of society-owned titles were published by third-parties. Having said this, the most recent edition of the International Association of Scientific, Technical and Medical Publishers (STM) Report (Ware and Mabe 2015) observed that "some learned societies now shy away from working with the largest commercial publishers" as a result of mistrust stemming from some of the rhetoric around OA publishing. Indeed the recent Untangling academic publishing report recommended that "[s]ocieties that co-publish journals or book series with third-parties should reflect on whether the mission and business strategy of the copublisher is a good fit for the society's scholarly mission" (Fyfe et al. 2017).

There is a tendency in such rhetoric to refer to the "large commercial publishers" as those with the most restrictive Green OA policies and a propensity opportunistically to take advantage of new income streams offered by Gold OA publishing. Analysis by Morris (2007), however, found that there was "no real difference" between the mean number of journals published by all publishers (2.39) and NFP publishers (2.32). The main differences lay in the fact that the "largest commercial publishers are very much larger than the largest non-profits" with the top four being responsible for almost $25 \%$ of all journals.

A publisher's type can lead to very different ways of engaging with the scholarly journals market, the main way being the prices charged for their products. Bergstrom and Bergstrom (2004) calculated that commercial journals cost 3-9 times more than non-profit journals and that the cost per citation was higher for commercial journals too. They observe that in the field of economics "the average inflation-adjusted price per page charged by commercial publishers has increased by $300 \%$ since 1985 , whereas that of nonprofit economics journals has increased by 'only' 50\%." (Bergstrom and Bergstrom 2004:897). In a more recent study, Liu and Gee (2017) found that commercial publishers charged, on average, over $102 \%$ more than non-commercial publishers, although again, there were disciplinary differences. Beyond profit margins, Morris (2007) observes that non-profits publish fewer new titles and close fewer titles than their commercial counterparts. She also found that $69 \%$ of the top 500 most cited science journals in the ISI indices were published by non-profit publishers. This suggests that non-commercial publishers are more cautious in the development of new titles, but the ones they publish have a significant impact on the scholarly community.

In terms of approaches to Green OA, Laakso's 2014 study of 100 large publishers (2014) found that $64 \%$ of titles published by commercial publishers would allow the self- 
archiving of the authors' accepted manuscript (AAM), compared to $71.1 \%$ of society publishers and $28.4 \%$ of university presses. Only six university presses (publishing 469 journals) were included in the sample so these figures should be treated with caution. $\mathrm{He}$ also found that society publishers were far more likely to allow authors to self-archive the published final version (36\%), than were commercial publishers $(1.3 \%)$ or university presses (0). Assuming society publishers tend to be the smaller publishers, this triangulates with Inger and Gardner's findings reported above (Inger and Gardner 2013). Covey (2009) found that the Green OA policies of for-profit publishers changed more frequently than non-profit publishers often causing a greater impact due to the number of journal titles under their control.

Laakso and Björk (2012:6) have also studied the growth of pure Gold OA journals over time by taking random stratified samples from the Directory of OA Journals (DOAJ) in 2000, 2005 and 2011. They find that "the early years of OA publishing were largely driven by scientific societies, professional associations, universities and their departments". However, since 2005 there has been a considerable leap in the number of pure OA journal titles offered by commercial publishers, resulting in an increase from 13,400 articles in 2005 to 119,900 in 2011. Using the same publisher categories Laakso and Björk (2013) went on to study journal publishers' approaches to delayed OA (defined as "scholarly articles in subscription journals made available openly on the web directly through the publisher at the expiry of a set embargo period"). They found that $98 \%$ of all delayed OA content stemmed from three publisher types: $52 \%$ by society publishers, $33 \%$ by commercial publishers and $13 \%$ by university presses. They note the difference between these proportions and the proportion of publishers overall in these categories, observing that society publishers were far more likely to make content available on a delayed OA basis than other types of publisher.

Whilst such analyses might suggest that learned societies are the most ready to engage with OA by offering liberal Green OA policies and delayed OA, it is interesting to note that in Pinfield et al's study on the total cost of publication (2016), nine of the top ten highest APCs are charged by society publishers-even though it is the large commercial publishers who dominate in terms of percentage share of the Gold and hybrid journals market.

\section{Country (UK/US)}

Morris (2007) noted that over half of the journals listed in Ulrichs were published either in the USA or the UK with $34 \%$ being US-based and 19\% being UK-based. As of May 2017, the SHERPA RoMEO database of 2375 journal publisher copyright policies included 558 (23\%) from the USA and $280(12 \%)$ from the UK. Whilst these proportions are slightly smaller, it is clear that the UK and the US are still the dominant players in the scholarly journal publishing market and no other country is home to so many.

It has often been observed how the US and the UK have differed in their approach to OA. In the US from the earliest beginnings of the NIH public access mandate in 2005, the preferred route was Green open access to the accepted manuscript, and this did not change when the Office for Science and Technology Policy (OSTP) instituted their public access to federally funded research memo in 2013. The policy required that all research (publications and data) funded by US federal agencies should be made available on OA with an allowable 12-month embargo period.

In the UK, the Finch report (2012:7) entitled Accessibility, Sustainability, Excellence: How to Expand Access to Research Publications concluded that "a clear policy direction should be set towards support for publication in open access or hybrid journals, funded by 
APCs, as the main vehicle for the publication of research, especially when it is publicly funded". The UK Research Councils (RCUK) then instituted an OA policy (2013) which stated that such Gold OA publishing was their preference (although Green OA would be acceptable within certain embargo periods) and they provided additional monies to UK HEIs with large tranches of RCUK funding to pay APCs. It is perhaps not surprising therefore that Laakso and Björk (2012) study of OA publishing showed that Europe had a far higher proportion of pure Gold OA articles than North America at all census points (2000, 2005 and 2011). Johnson et al. (2017:6) also observed that within Europe, "countries [such as the UK] with a significant academic publishing industry are more likely to favour Gold OA".

Despite this propensity towards Gold in the UK by the core Government funding agencies, Archambault et al. (2014) found that there was more variety in funder OA policies in the UK than the US, with the UK having the largest volume of funder OA mandates (34) followed by Canada (14), the US (9), Denmark (6), Ireland (5), and France (5). Of course, funding agencies do not exclusively fund research performed within the national base, and researchers world-wide may find their work subject to an OA policy that was devised elsewhere.

\section{Methods}

In order to better understand publisher approaches to open access over time, publisher OA policy information was extracted from the SHERPA/RoMEO database (SHERPA, [n.d.]) using the Internet Archive "Wayback Machine" . The SHERPA/RoMEO database arose out of the Jisc-funded RoMEO Project (Gadd et al. 2003). At its inception in 2004, 107 journal publishers were listed although by May 2017 this had grown to 2375 publishers. The database's updating procedures are not publicly documented, but correspondence with the service provider reassured the authors that "Romeo is updated on a regular basis, with the processing of updates to records, taking priority over the addition of new records. [They] also work with...international partners to carry out routine audits of [their] data, to ensure that... records are regularly refreshed" [Personal correspondence with RoMEO service, 2018].

The database colour codes both publishers and individual journal titles as 'yellow', 'blue', 'green' or 'white' according to whether their OA policy allows authors to selfarchive (respectively) the pre-print, post-print, both or neither. Some publishers issue a range of journals under a variety of different policies, particularly where titles are owned by learned societies. Approximately $15 \%$ of the original 107 publishers on the RoMEO database offered journals under a variety of policies (Gadd and Troll Covey 2016: 12). However, the RoMEO database also allocates publishers a 'default' policy position. As the study sought to understand publisher-level approaches to OA, it used the default policy position for analysis rather than individual journal titles. This was also a pragmatic choice as the study involved manually coding of 100 publisher policies over 13 years on five different policy aspects-a total of 6500 data points.

In addition to the colour-coding, RoMEO also provides policy summaries for each publisher, listing the restrictions and conditions under which self-archiving may take place, and whether they offer a paid open access option. Until 2010, all of this data appeared on a single page $\mathrm{A}-\mathrm{Z}$ listing. However, from 2010 onward, the single page $\mathrm{A}-\mathrm{Z}$ listing only

\footnotetext{
${ }^{1}$ Further details about the "Wayback Machine" can be found at: https://archive.org/web/.
} 
provided the colour codes and a link to a policy summary page for each individual publisher. The Internet Archive was searched for archived full A-Z listings from the http:// www.sherpa.ac.uk/romeo website. At least one full list was available for each year from 2004 to 2016 giving the overall RoMEO colour codes. However, the changes in 2010 meant that no policy summary data were available for that year and was very patchy during 2011 and 2012. Where no summary was available for a particular publisher in a particular year, the last known policy summary for that publisher was carried forward. As a result, the findings presented here slightly under-report the volume of policy changes rather than over-report them.

During the period studied, seven of the original 107 publishers changed their characteristics regarding the units of analysis used in this study (e.g. size, type, or even country) through mergers and acquisitions. As the research questions sought to understand whether a publisher's characteristics affected their OA policy over time, it was necessary to remove these publishers and focus on the remaining 100 whose characteristics remained the same over the 13 years under study. Each of the 100 publishers was allocated a type according to their status: commercial, university press, learned or professional society (from here on in, 'learned society') or 'other'. Then, using a combination of the Ulrich's Global Serials Directory, the RoMEO database and publisher websites, the publisher's country along with the number of current active titles they published was determined. Clearly a publisher's journal portfolio does not remain static, however their current journal list served as an indication of size for the purposes of analysis. Using Inger and Gardner's (2013) classification, a publisher was denoted as small if it had 1-10 titles, medium if it owned 11-99, and large if it owned 100 or more titles. A list of the publishers and their demographics is given in "Appendix".

By studying 100 of the original 107 publishers on the RoMEO database, rather than taking a sample of publishers from each year, we were able to capture 13 years-worth of data for the participating group, enabling us to trace changes to their policies over a significant period of time. An additional benefit of this method was that, unlike other studies (e.g. Miguel et al. (2011) and Laakso (2014)) which only examined the policies of larger publishers (i.e., mainly commercial publishers based in the UK or USA), this group represented a greater range of publisher types, sizes and nationalities. However, due to the small sample size the findings may only be viewed as indicative rather than predictive of the wider journal publisher population. Due to the small number of non-UK or US publishers in the sample, only UK and US publishers were included in the country-based analyses.

For each publisher, the number of restrictions relating to the 'where', 'when' and 'how' of self-archiving were counted and coded, as was the availability of a paid OA option and the RoMEO colour code. A 'where' restriction referred to the various locations of deposit allowed by the publisher, such as a personal webpage, a non-commercial site, or an institutional repository. A 'when' restriction mainly referred to a publisher's embargo period, but could also include a restriction on self-archiving prior to publication. A 'how' restriction referred to the range of other stipulations made by the publisher such as acknowledging the publisher using a set form of wording and linking to the published version. As was explored in the earlier study (Gadd and Troll Covey 2016), just because a publisher was allocated a 'white' colour code, it did not mean that they did not allow any self-archiving, only that they did not permit it immediately. Thus a 'white' publisher may still have a series of 'where', 'when' and 'how' restrictions relating to the embargoed selfarchiving they allowed. 
Again, as noted in the previous study, the volume of restrictions around where an item might be self-archived grew significantly over time, principally due to the increase in 'linked embargos' (where an embargo period varied according to another factor). Thus a single or group of allowed deposit locations was counted as one 'where' restriction, but if additional 'where' restrictions related to particular location types, they were counted separately. For example, if it was permissible to make a post-print available on a personal or institutional web page, that counted as a single 'where' restriction. However, if it was permissible to make a post-print available on a personal web page immediately, and on an institutional repository after 12 months, this would be counted as two 'where' restrictions. It should be noted that due to reasons of space this study does not explore the content of the 'how', 'where' and 'when' restrictions, just the number. Where a publisher has a higher volume of restrictions, it makes is increasingly complicated for authors and Institutional Repository managers to comply with their policy.

To test the significance of the policy changes by each demographic group between 2004 and 2016, the non-parametric Kruskal-Wallis test was applied to the resulting non-normally distributed data to assess the significance of the variance of the means over time.

\section{Findings}

\section{Demographic analysis of the publishers studied}

Table 2 shows the distribution of the 100 publishers by size and type. It can be seen that of the 17 commercial publishers, the majority, 15, were large. Two of the university presses (Oxford and Cambridge) were large, whilst the remainder were equally split across the medium and small groups. Not surprisingly, no learned society publisher was classified as large, and the majority were small (40), although a good proportion were medium-sized (24). This may be an artefact of the origin of the RoMEO database as an attempt to document the policies of the most prolific and presitigious journals (Gadd et al. 2003). Those publishers classified as 'other' were either government or other non-profit organisations.

Table 3 shows the countries in which the 100 publishers were based. Three were multinational, but of the remaining 97, 87 (89\%) were either based in the UK (27) or the USA (60).

Table 2 Distribution of publishers studied by size and type

\begin{tabular}{lcccr}
\hline Publisher type/size & Large $(100+$ titles $)$ & Medium $(11-99$ titles $)$ & Small $(1-10$ titles $)$ & Total \\
\hline Commercial & 15 & 2 & 0 & 17 \\
University Press & 2 & 7 & 7 & 16 \\
Society & 0 & 24 & 40 & 64 \\
Other & 0 & 2 & 1 & 3 \\
Total & 17 & 35 & 48 & 100 \\
\hline
\end{tabular}


Table 3 Distribution of publishers by country

\begin{tabular}{lc}
\hline & Number publishers \\
\hline Multinational & 3 \\
USA & 60 \\
UK & 27 \\
Canada & 2 \\
Netherlands & 1 \\
Australia & 2 \\
Germany & 2 \\
Japan & 1 \\
India & 1 \\
Sweden & 1 \\
Total & 100 \\
\hline
\end{tabular}

\section{Findings relating to publisher size}

\section{Publisher size and RoMEO colour code}

Figure 1 shows the starting profile (2004) and ending profile (2016) of the colour codes allocated to publishers broken down by publisher size. The chart demonstrates visible differences between the groups. It is interesting to observe that both the small and medium publisher groups saw a reduction in white and a growth of green publishers over the timeframe. However, smaller publishers were still more likely to be 'white' (allowing no selfarchiving at all) both at the beginning and the end of the time period. Larger publishers saw a slight reduction in green in favour of yellow. The samples of course were small and so we should be wary of making generalizations, however, these findings would chime with Inger and Gardner's (2013) study where smaller publishers were less likely to allow the selfarchiving of pre- or post-print despite getting more permissive over time whilst larger publishers got more restrictive.

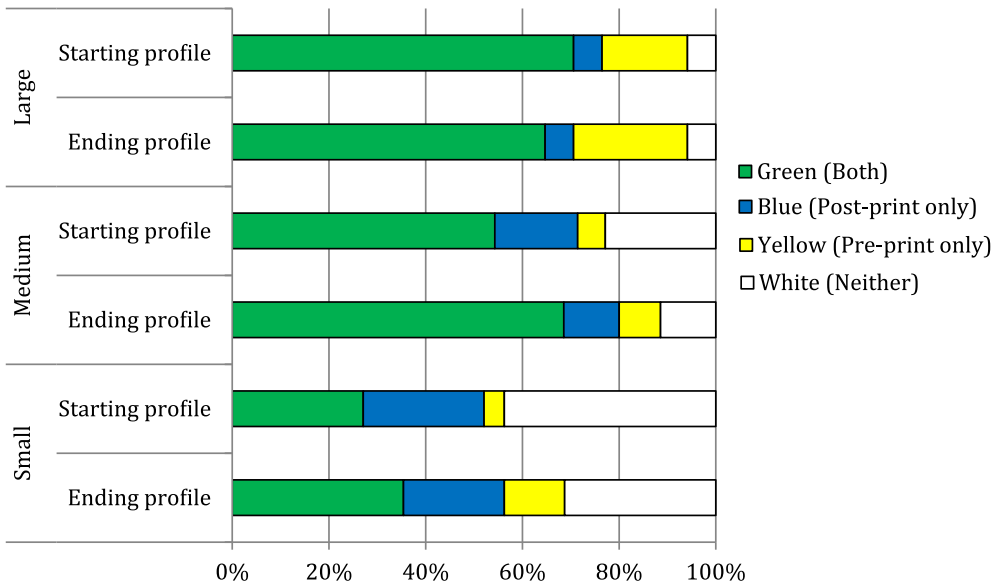

Fig. 1 Starting (2004) and ending (2016) colour profile of publishers by size 


\section{Publisher size and self-archiving restrictions}

Figure 2 shows the growth in the mean number of restrictions regarding when, where and how an item might be self-archived according to publisher size.

The data show that on restrictions relating to when an item might be self-archived (solid line), all publishers started from a similarly low base. However, whilst medium and large publishers grew to mean of just under one 'when' restriction each, smaller publishers placed far fewer restrictions on when items might be self-archived with a mean of 0.23. A similar disparity between small and either medium or large publishers could be seen in terms of 'where' restrictions with smaller publishers issuing far fewer restrictions as to where an item might be self-archived relative to their larger counterparts. For larger publishers this grew from a mean of less than one to more than two over the period. The greatest disparity between the three groups was on the mean number of 'how' restrictions placed on self-archiving. Smaller publishers have remained relatively stable with about 0.5 'how' restrictions per publisher, however, despite medium and large publishers both starting from the same base (1.4), medium publishers grew to an average of 2.5 over the timeframe, whilst larger publishers grew to 3.3. A Kruskal-Wallis test on the differences between the 2004 and 2016 data showed a significant difference $(p<0.05$ at the $95 \%$ confidence level) between the groups on 'where' and 'how' restrictions over time, but not on the 'when' restrictions.

\section{Publisher size and paid OA options}

Figure 3 shows the growth over time of the percentage of small, medium and large publishers with paid open access options.

It is very clear that the larger and medium publishers have seen a considerably greater rate of growth over the period than small publishers. By 2016, $82 \%$ of large publishers in the sample offered a paid open access option compared to less than $10 \%$ of smaller

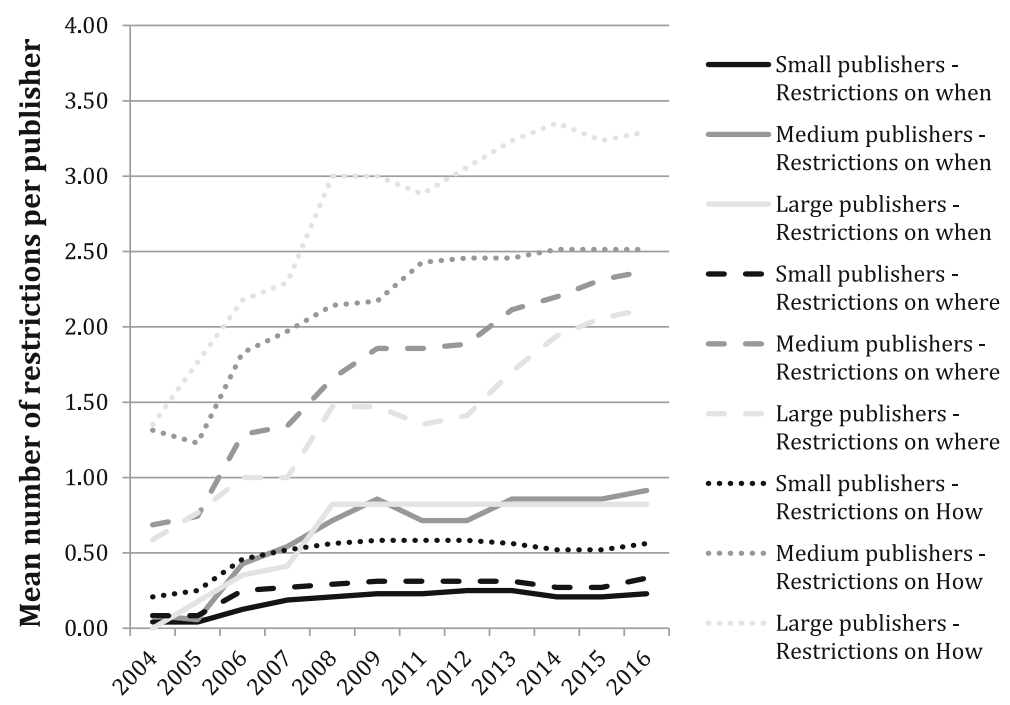

Fig. 2 Mean number of restrictions on self-archiving by publisher size over time. NB. Data were unavailable for 2010 


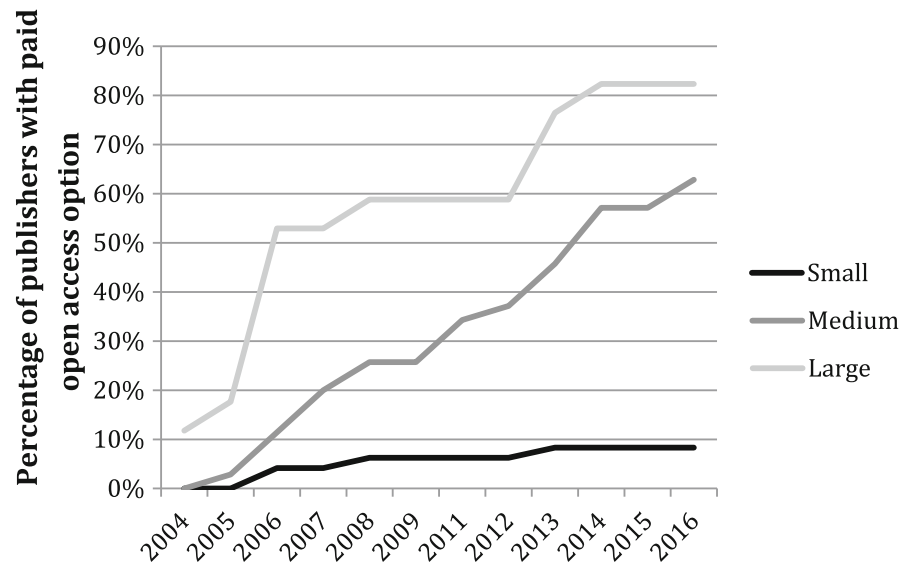

Fig. 3 Percentage of publishers with a paid open access option by size. NB. Data were unavailable for 2010

publishers. Not surprisingly, a Kruskal-Wallis Test showed a significant difference between the three groups in 2004 and 2016 with $p<0.005$.

\section{Findings relating to publisher type}

\section{Publisher type and colour code}

Figure 4 shows the starting profile (2004) and ending profile (2016) of the colour codes allocated to publishers broken down by publisher type. The 'Other' publishers were excluded from these analyses as the group size was too small.

Once again there are visible differences between the colour codes of the three categories. The commercial publishers' position remains fairly static over the timeframe. However, university presses increased in their proportion of both green and white publishers almost to the exclusion of blue and yellow. Learned society publishers also increased their proportion of green and yellow, but reduced their volume of white.

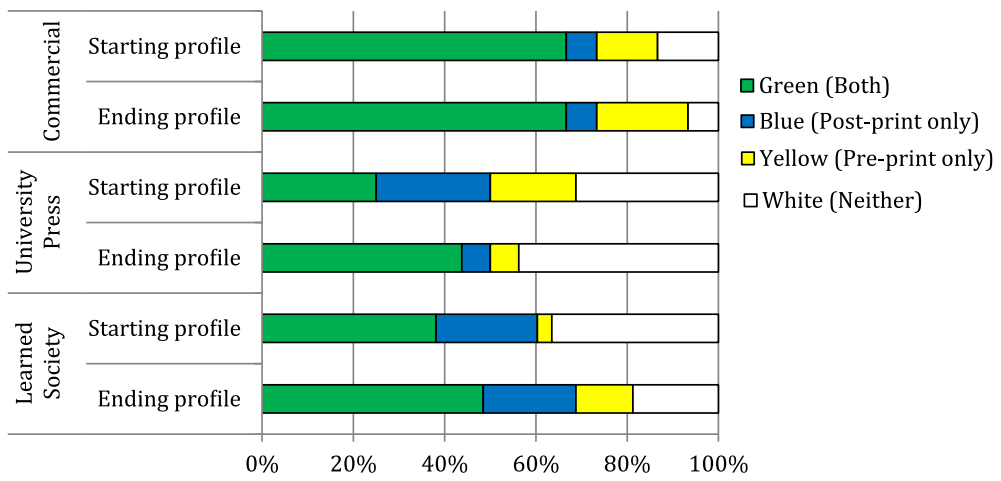

Fig. 4 Starting (2004) and ending (2016) colour profile of publishers by type 


\section{Publisher type and self-archiving restrictions}

Figure 5 shows the growth in the mean number of restrictions regarding when, where and how an item might be self-archived according to publisher type.

Looking at the data for the growth of 'when' restrictions (solid line), we see that all the groups went from almost zero to just under one restriction per publisher over the period. The growth of 'where' restrictions (dashed line) also follow a very similar pattern, with commercial publishers having slightly more restrictions than university presses who in turn have more than learned societies. The most visible differences were to be found in the growth rate of 'how' restrictions. In 2016 learned societies had an average of two restrictions, whereas university presses had 2.3 and commercial publishers had 3.5. Despite the apparent differences on 'how' restrictions, a Kruskal-Wallis test determined that none of these differences were statistically significant.

\section{Publisher type and paid OA options}

Figure 6 shows the growth over time of the percentage of different publisher types offering paid open access options.

Once again, the differences between the three groups are clearly apparent. Commercial publishers made considerable gains in Gold OA publishing in 2006 and 2013. By the end of the 13-year timeframe, $87 \%$ of commercial publishers have a paid open access option compared to $47 \%$ of learned societies and $25 \%$ of university presses. A Kruskal-Wallis test shows that these are differences are significant at $p<0.05$.

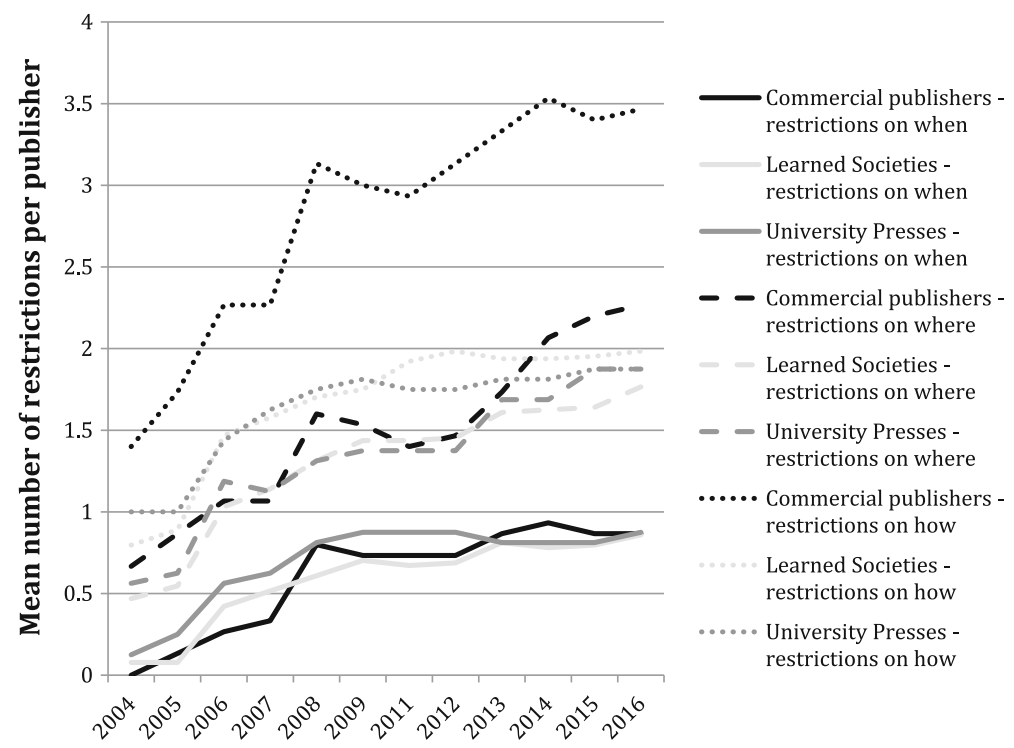

Fig. 5 Mean number of restrictions on self-archiving over time-by type. NB. Data were unavailable for 2010 


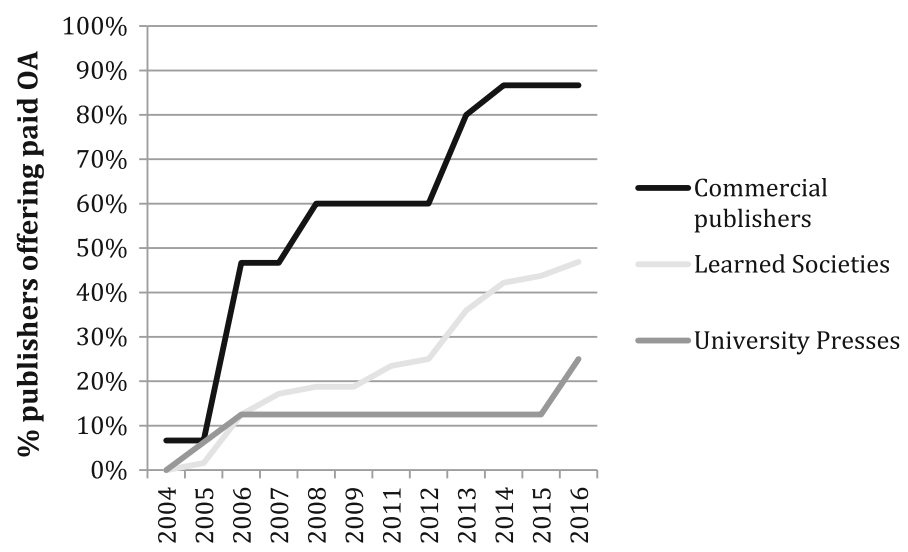

Fig. 6 Percentage of publishers with a paid open access option-by type. NB. Data were unavailable for 2010

\section{Findings relating to UK and US publishers}

\section{Publisher country and colour code}

Figure 7 shows the changes in the UK and US publishers' RoMEO colour code profile between 2004 (starting profile) and 2016 (ending profile). Interestingly, the proportion of UK publishers with a green colour code remains static although the proportion of yellow increases significantly, with white reducing to less than $10 \%$. In the US the number of green publishers grows from 24 in 2004 to 32 in 2016, displacing the volume of white. A Chi Square test showed that the ending profiles were not statistically significantly different however. Around 80\% of both sets of publishers allow some form of OA in 2016.

\section{UK and US publishers and restrictions}

Figure 8 shows the average number of restrictions on self-archiving by country (UK and US) over the timeframe. It can be seen that UK publishers have grown to impose a higher level of 'when' (e.g. embargo) restrictions than their US counterparts. However, the

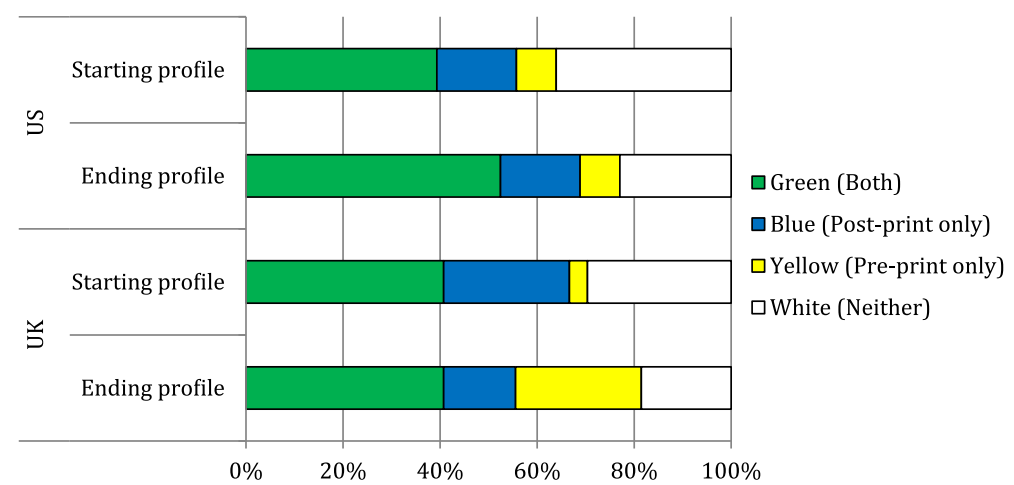

Fig. 7 Starting (2004) and ending (2016) colour profile of publishers by country 


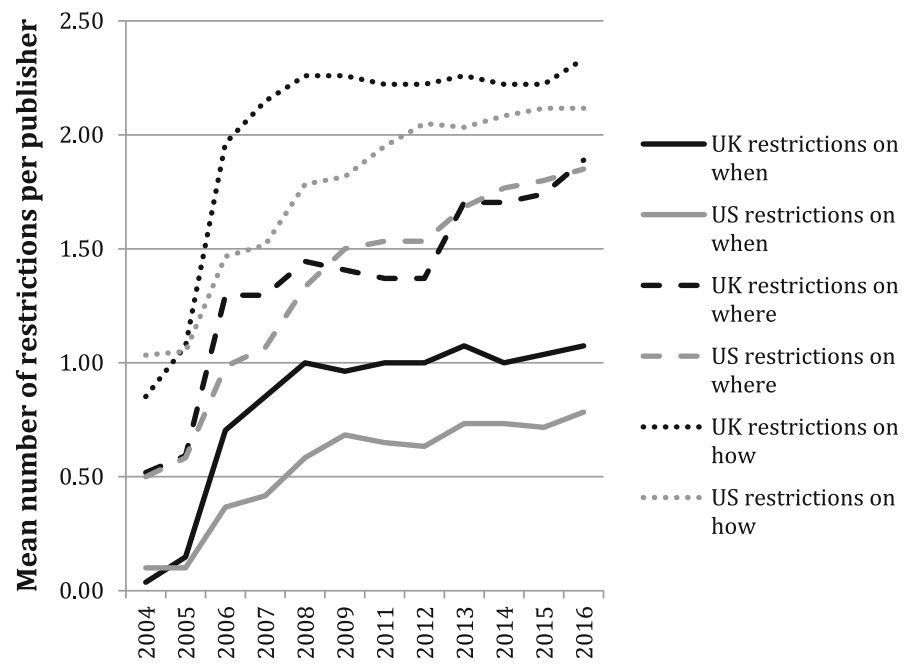

Fig. 8 Mean number of restrictions on self-archiving over time-by country. NB. Data were unavailable for 2010

volume of 'where' restrictions has followed a similar path. Interestingly, the growth rate of 'how' restrictions was much steeper in the UK in the latter half of the last decade (2005-8) whereupon it seemed to plateau. Growth in the US was steadier but is still above a mean of two per publisher. The change in starting and ending profiles was only significantly different for 'how' restrictions.

\section{UK and US publishers and paid OA options}

Figure 9 shows the growth in paid OA options amongst UK and US publishers over the timeframe. It is clear that the growth rate in the UK has been considerably greater than in the US. By 2016 two-thirds (67\%) of the UK publishers had a paid OA option according to

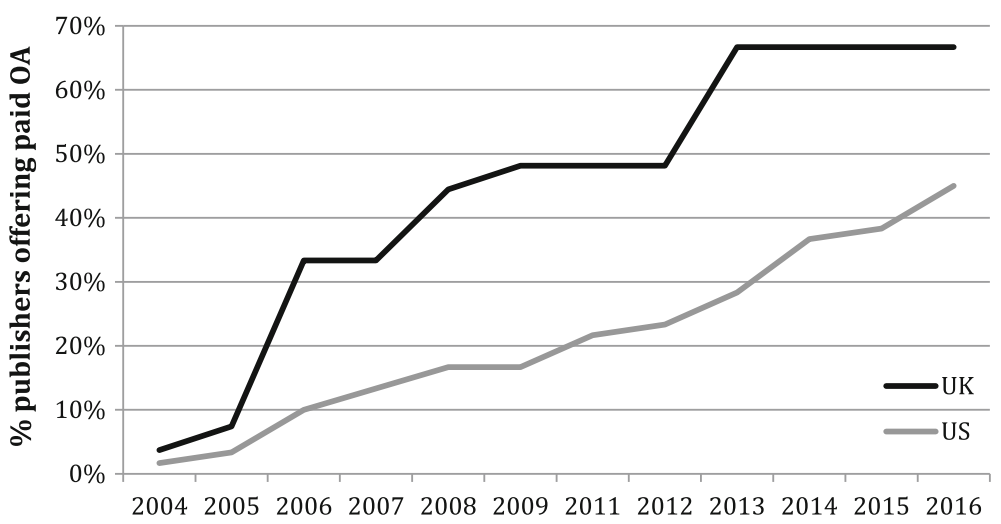

Fig. 9 Percentage of publishers with a paid open access option over time-by country. NB. Data were unavailable for 2010 
the RoMEO database, whereas less than half of US publishers did so (45\%). These were not found to be significant differences.

\section{Discussion}

As observed in an earlier study, the volume of restrictions in journal publishers' OA policies as to 'when', 'where' and 'how' authors might self-archive, and the existence of paid OA options, has grown exponentially over time (Gadd and Troll Covey 2016). However this study shows that this growth has not been evenly distributed across publishers. Our findings reveal some significant differences between journal publisher OA policies according to the publisher's size, type and the country in which they are based.

It should be noted that the spread of publishers across the categories is not even. The smaller publisher category is dominated by learned society publishers (40/48) and the larger publisher category is dominated by commercial publishers (15/17). Unfortunately, there was not enough data to try to understand which of the two characteristics (publisher size or type) were the most important in the development of a publisher's OA policy. The findings are discussed through each of the three lenses (size, type and country) below.

\section{Publisher size}

It is interesting to observe that despite large publishers, and to an increasing extent medium-sized publishers, developing permissive OA policies that allocate them a RoMEO 'green', 'blue' or 'yellow' colour code, when it comes to the detail of those policies the picture is quite different. The findings reveal that smaller publishers are significantly less restrictive than their medium and large counterparts in terms of 'where', 'where' and 'how' their authors might self-archive. By 2016, large publishers had approximately one-third more 'how' restrictions than medium publishers and about six times as many as small publishers. Interestingly, medium-sized publishers have a $10 \%$ higher mean number of restrictions around 'where' a paper might be self-archived than larger publishers, and seven times as many 'where' restrictions as small publishers. All of this is against a backdrop of very high levels of paid OA growth amongst large publishers, with medium-sized publishers following closely behind. It was very unusual for the smaller publishers in this study to have a paid OA option, however, we should note that none of the smaller publishers included were designated as commercial.

Clarke (2015) observes that smaller, usually learned society, publishers lack the 'horizontal scale' to fully engage with the Gold open access market. However, they do possess 'vertical scale' which he describes as an in-depth relationship with a particular sector to which they are able to sell a range of different services. It is perhaps a combination of this connection with their community and their lack of ability to develop large paid OA programmes that has resulted in a subset of smaller learned society publishers with relatively permissive Green OA policies and no Gold option. However, it should be noted that of the 35 medium-sized publishers included in this study, 24 (69\%) were learned society publishers. It would be wrong therefore to categorise all learned society publishers in the same way. What we are observing here is a markedly different approach to OA amongst smaller publishers than medium or large-sized ones. 


\section{Publisher type}

The findings relating to publisher type once again show significant differences between the OA approaches of commercial, university press and learned society publishers. The RoMEO colour code analysis corroborates Laakso's 2014 study which found that university presses were less likely $(28.4 \%)$ than commercial $(64 \%)$ or learned society $(71 \%)$ publishers to allow the self-archiving of the AAM. Laakso's study only included six university presses so it is useful to be able to triangulate his finding with a larger sample size. Indeed, in this study, the university presses were the only group to actually reduce the proportion of publishers with either a 'green', 'blue' or 'yellow' colour code over the time period.

Once again the commercial publishers had a far higher proportion with a colour code at all $(93 \%)$ but they also had considerably higher rates of 'how' restrictions $(75 \%$ higher than university presses and learned societies) and 'where' restrictions (20-30\% higher). An interesting finding in this particular analysis was the very similar growth patterns amongst publishers of all types with regards to the volume of 'when' restrictions. This may be as a result of all publishers working in the same external policy environment regarding funder embargo period requirements. Of course, if the content of those restrictions underwent analysis (i.e. the length of permitted embargo periods) it might be that marked differences would be found.

The paid OA analysis, not surprisingly, showed that commercial publishers were significantly more likely to offer a Gold OA option than learned societies or university presses. This correlates with the findings of Johnson et al (2017) that the open access publishing market is dominated by "a few large commercial companies" who "have gained market share largely at the expense of smaller non-profit publishers, such as learned society publishers". However, our study suggests that learned societies are showing steady growth in the development of paid OA options with almost $50 \%$ of those studied having such an option by 2016. The university presses were the least likely to have a paid OA option; indeed there was no growth at all in this category between 2006 and 2015.

It is interesting to consider the future of university presses in an open access world in the light of these findings. It would appear that they are currently neither pursuing Green nor Gold open access strategies. Of course our sample was small (16) and diverse (from the large Oxford University Press through to the single-title Michigan Law Review). However, concern about the university press sector has also been expressed by Clarke (2016) who suggests they are 'Neither fish nor fowl'. He fears that they are not well-placed to follow the "Leviathan" strategies of large commercial enterprises, nor the "Community" strategies of small learned societies. However, if more Universities start to develop their own presses in response to discontent about the world of commercial scholarly publishing (Speicher 2016) it will be interesting to watch how this category of publishers changes over time, perhaps with more distinctive (and liberal) approaches to OA.

\section{Publisher country (UK \& US)}

The influence of national OA policy environments could be observed amongst the findings relating to UK and US publishers. The growth in 'green' RoMEO colour codes amongst US publishers over the study period may be in direct response to the US OSTP policy (OSTP 2013) which mandates the self-archiving of accepted government-funded research. By contrast, UK publishers offered a considerably higher proportion of paid OA options than US publishers. Indeed, the two growth spurts in the proportion of UK publishers 
offering paid OA (in 2006 and 2013) map directly on to the introduction of the first Research Councils UK (RCUK) OA mandate in 2006 where they approved the use of RCUK grants to pay APCs (Suber 2006) and the updated post-Finch policy in 2013 which stated a preference for Gold OA and offered separate tranches of funding to pay for this (RCUK 2013). In fact, it's not beyond the realms of possibility that the reduction in 'blue' and increase in 'yellow' colour codes amongst UK publishers over the timeframe might be in an effort to discourage the Green self-archiving of the AAM in an effort to encourage authors to pursue paid Gold OA instead.

Further evidence of the impact of national policy environments can be seen in the growth of 'when', 'where' and 'how' restrictions. Both UK and US publishers see an increase in 'when' and 'where' restrictions in 2006, probably as a result of the first RCUK OA mandate, a new Wellcome Trust (2005) OA mandate and the first US National Institutes for Health OA policy (NIH 2005) which requested the submission of the author's final manuscript upon acceptance for publication (or within 12 months) to the NIH National Library of Medicine's (NLM) PubMed Central (PMC). As discussed in the earlier paper, the growth in mentions of the PubMed Central Repository, and the increase in 12 month embargo periods during this period is notable (Gadd and Troll Covey 2016).

\section{Conclusions and recommendations for further study}

The original research questions asked whether a publisher's size, type or country affected their Green OA policy as to what, when, how and where papers may be self-archived and the likelihood that they will offer a Gold OA option. The findings clearly indicate that a journal publisher's demographics do have an influence on their OA policy. Large commercial publishers are more likely to be allocated a RoMEO colour code, but at the same time place a high volume of restrictions as to when, where and how the author's manuscript might be self-archived, perhaps in an effort to steer authors towards engaging with their growing paid OA services. Small publishers may look less supportive of Green open access according to their RoMEO colour codes, but the volume of restrictions they place on self-archiving are minimal. University presses appear not to be engaging with either OA agenda to any considerable degree and a study of the development of new university presses would be interesting in this regard. Whilst the data is not conclusive, UK and US publishers' OA policies appear to be very much influenced by the national OA policy environment which, considering the global nature of the scholarly journals market, was more pronounced than might have been anticipated. Further study is required to determine whether this result is particular to the UK/US environments, or has wider applicability.

Of course, a study that looks only at the volume of 'when', 'where' and 'how' restrictions rather than looking at the content of those restrictions can only draw limited conclusions. A further study is recommended in which publishers are viewed through a single demographic lens (publisher type would perhaps be the most interesting) in which the content of their policies (e.g., the length of embargo periods and allowable deposit locations) are analysed in some detail. The other natural limitation of this study was the small volume of publishers (100) for whom we had a full 13-years-worth of data. Taking a random stratified sample of publishers of different types from the current year would provide a much larger sample size from which predictive rather than indicative results could be drawn. Having access to such data would make it possible to revisit the final analysis in the Gadd and Troll Covey study (2016) in which the number of publishers 
adhering to the RoMEO definition of 'green' were compared to the number of those adhering to a revised definition of green whereby the AAM could be made available in an Institutional Repository immediately upon acceptance. Overall, publishers meeting the revised definition of green were in decline, however, it would be informative to understand whether this was true of all publishers, or only those in certain demographic groups. Such evidence might be a useful tool in guiding authors as to where the most liberal OA policies might be found, and further support the progress of the open access agenda.

Open Access This article is distributed under the terms of the Creative Commons Attribution 4.0 International License (http://creativecommons.org/licenses/by/4.0/), which permits unrestricted use, distribution, and reproduction in any medium, provided you give appropriate credit to the original author(s) and the source, provide a link to the Creative Commons license, and indicate if changes were made.

\section{Appendix}

\section{See Table 4.}

Table 4 List of publishers studied

\begin{tabular}{|c|c|c|c|}
\hline Publisher name & Size & Type & Country \\
\hline Academy of Management & Small & $\begin{array}{l}\text { Learned } \\
\text { Society }\end{array}$ & US \\
\hline American Anthropological Association & Medium & $\begin{array}{l}\text { Learned } \\
\text { Society }\end{array}$ & US \\
\hline American Association for the Advancement of Science & Small & $\begin{array}{l}\text { Learned } \\
\text { Society }\end{array}$ & US \\
\hline American Chemical Society & Medium & $\begin{array}{l}\text { Learned } \\
\text { Society }\end{array}$ & US \\
\hline American Economic Association & Small & $\begin{array}{l}\text { Learned } \\
\text { Society }\end{array}$ & US \\
\hline American Geophysical Union (AGU) & Medium & $\begin{array}{l}\text { Learned } \\
\text { Society }\end{array}$ & US \\
\hline American Institute of Aeronautics and Astronautics & Small & $\begin{array}{l}\text { Learned } \\
\text { Society }\end{array}$ & US \\
\hline American Institute of Physics & Medium & $\begin{array}{l}\text { Learned } \\
\text { Society }\end{array}$ & US \\
\hline American Mathematical Society & Medium & $\begin{array}{l}\text { Learned } \\
\text { Society }\end{array}$ & US \\
\hline American Medical Association & Medium & $\begin{array}{l}\text { Learned } \\
\text { Society }\end{array}$ & US \\
\hline American Meteorological Society & Medium & $\begin{array}{l}\text { Learned } \\
\text { Society }\end{array}$ & US \\
\hline American Physical Society & Medium & $\begin{array}{l}\text { Learned } \\
\text { Society }\end{array}$ & US \\
\hline American Physiological Society & Medium & $\begin{array}{l}\text { Learned } \\
\text { Society }\end{array}$ & US \\
\hline American Psychological Association & Medium & $\begin{array}{l}\text { Learned } \\
\text { Society }\end{array}$ & US \\
\hline American Public Health Association & Small & $\begin{array}{l}\text { Learned } \\
\text { Society }\end{array}$ & US \\
\hline
\end{tabular}


Table 4 continued

\begin{tabular}{|c|c|c|c|}
\hline Publisher name & Size & Type & Country \\
\hline American Society for Clinical Investigation & Small & $\begin{array}{l}\text { Learned } \\
\text { Society }\end{array}$ & US \\
\hline American Society for Microbiology & Medium & $\begin{array}{l}\text { Learned } \\
\text { Society }\end{array}$ & US \\
\hline $\begin{array}{l}\text { American Society for Pharmacology and Experimental } \\
\text { Therapeutics }\end{array}$ & Small & $\begin{array}{l}\text { Learned } \\
\text { Society }\end{array}$ & US \\
\hline American Society of Civil Engineers & Medium & $\begin{array}{l}\text { Learned } \\
\text { Society }\end{array}$ & US \\
\hline American Society of Hematology & Small & $\begin{array}{l}\text { Learned } \\
\text { Society }\end{array}$ & US \\
\hline American Society of Limnology and Oceanography (ASLO) & Small & $\begin{array}{l}\text { Learned } \\
\text { Society }\end{array}$ & US \\
\hline American Society of Plant Biologists & Small & $\begin{array}{l}\text { Learned } \\
\text { Society }\end{array}$ & US \\
\hline American Sociological Association & Small & $\begin{array}{l}\text { Learned } \\
\text { Society }\end{array}$ & US \\
\hline Annual Reviews & Medium & Other & US \\
\hline Association for Computing Machinery & Medium & $\begin{array}{l}\text { Learned } \\
\text { Society }\end{array}$ & US \\
\hline Association for the Advancement of Computing in Education & Small & $\begin{array}{l}\text { Learned } \\
\text { Society }\end{array}$ & US \\
\hline Association of Applied Biologists & Small & $\begin{array}{l}\text { Learned } \\
\text { Society }\end{array}$ & UK \\
\hline Australian Academic Press & Medium & $\begin{array}{c}\text { University } \\
\text { Press }\end{array}$ & Australia \\
\hline Australian Computer Society Inc & Small & $\begin{array}{l}\text { Learned } \\
\text { Society }\end{array}$ & Australia \\
\hline Berkeley Electronic Press & Medium & $\begin{array}{l}\text { University } \\
\text { Press }\end{array}$ & US \\
\hline BioMed Central & Large & Commercial & UK \\
\hline BMJ Publishing Group & Large & Commercial & UK \\
\hline British Institute of Non-destructive Testing & Small & $\begin{array}{l}\text { Learned } \\
\text { Society }\end{array}$ & UK \\
\hline CAB International Publishing & Small & $\begin{array}{l}\text { Learned } \\
\text { Society }\end{array}$ & UK \\
\hline Cambridge University Press & Large & $\begin{array}{l}\text { University } \\
\text { Press }\end{array}$ & UK \\
\hline $\begin{array}{l}\text { Clinical Laboratory Science (Later American Society for Clinical } \\
\text { Laboratory Science) }\end{array}$ & Small & $\begin{array}{l}\text { Learned } \\
\text { Society }\end{array}$ & US \\
\hline Company of Biologists & Small & $\begin{array}{l}\text { Learned } \\
\text { Society }\end{array}$ & UK \\
\hline Ecological Society of America & Small & $\begin{array}{l}\text { Learned } \\
\text { Society }\end{array}$ & US \\
\hline Electrochemical Society & Small & $\begin{array}{l}\text { Learned } \\
\text { Society }\end{array}$ & US \\
\hline Elsevier & Large & Commercial & Multinational \\
\hline Emerald & Large & Commercial & UK \\
\hline
\end{tabular}


Table 4 continued

\begin{tabular}{|c|c|c|c|}
\hline Publisher name & Size & Type & Country \\
\hline Endocrine Society & Small & $\begin{array}{l}\text { Learned } \\
\text { Society }\end{array}$ & US \\
\hline Evolutionary Ecology & Small & $\begin{array}{l}\text { Learned } \\
\text { Society }\end{array}$ & US \\
\hline Geological Society & Small & $\begin{array}{l}\text { Learned } \\
\text { Society }\end{array}$ & UK \\
\hline Geological Society of America & Small & $\begin{array}{l}\text { Learned } \\
\text { Society }\end{array}$ & US \\
\hline Georgetown University Law Center & Medium & $\begin{array}{l}\text { University } \\
\text { Press }\end{array}$ & US \\
\hline Hindawi Publishing Corporation & Large & Commercial & US \\
\hline Imperial College Press & Small & $\begin{array}{l}\text { University } \\
\text { Press }\end{array}$ & UK \\
\hline Institute of Biology/Society of Biology & Small & $\begin{array}{l}\text { Learned } \\
\text { Society }\end{array}$ & UK \\
\hline $\begin{array}{l}\text { Institute of Electrical (Later Electronics), Information and } \\
\text { Communication Engineers }\end{array}$ & Medium & $\begin{array}{l}\text { Learned } \\
\text { Society }\end{array}$ & Japan \\
\hline Institute of Electrical and Electronics Engineers (IEEE) & Large & Commercial & US \\
\hline Institute of Mathematical Statistics & Medium & $\begin{array}{l}\text { Learned } \\
\text { Society }\end{array}$ & US \\
\hline Institute of Physics later IOP Publishing & Medium & $\begin{array}{l}\text { Learned } \\
\text { Society }\end{array}$ & UK \\
\hline Institution of Chemical Engineers & Small & $\begin{array}{l}\text { Learned } \\
\text { Society }\end{array}$ & UK \\
\hline Institution of Electrical Engineers (IEE) Later IET & Medium & $\begin{array}{l}\text { Learned } \\
\text { Society }\end{array}$ & UK \\
\hline International Press & Medium & Commercial & US \\
\hline International Union of Pure and Applied Chemistry & Small & $\begin{array}{l}\text { Learned } \\
\text { Society }\end{array}$ & US \\
\hline Internet Journal of Chemistry & Small & Other & US \\
\hline IOS Press & Large & Commercial & Netherlands \\
\hline John Wiley \& Sons, Inc. & Large & Commercial & US \\
\hline Johns Hopkins University Press & Medium & $\begin{array}{l}\text { University } \\
\text { Press }\end{array}$ & US \\
\hline Lippincott, Williams \& Wilkins & Large & Commercial & US \\
\hline Mary Ann Liebert & Medium & Commercial & US \\
\hline Massachusetts Institute of Technology Press & Medium & $\begin{array}{l}\text { University } \\
\text { Press }\end{array}$ & US \\
\hline Massachusetts Medical Society & Small & $\begin{array}{l}\text { Learned } \\
\text { Society }\end{array}$ & US \\
\hline Materials Research Society & Small & $\begin{array}{l}\text { Learned } \\
\text { Society }\end{array}$ & US \\
\hline Medknow Publications & Large & Commercial & India \\
\hline Michigan Law Review & Small & $\begin{array}{l}\text { University } \\
\text { Press }\end{array}$ & US \\
\hline National Academy of Science & Small & $\begin{array}{l}\text { Learned } \\
\text { Society }\end{array}$ & US \\
\hline National Research Council Canada (Now NRC Press) & Medium & Other & Canada \\
\hline
\end{tabular}


Table 4 continued

\begin{tabular}{|c|c|c|c|}
\hline Publisher name & Size & Type & Country \\
\hline Nature Publishing Group & Large & Commercial & UK \\
\hline Nordic Ecological Society & Small & $\begin{array}{l}\text { Learned } \\
\text { Society }\end{array}$ & Sweden \\
\hline Oceanography Society & Small & $\begin{array}{l}\text { Learned } \\
\text { Society }\end{array}$ & US \\
\hline Optical Society of America & Medium & $\begin{array}{l}\text { Learned } \\
\text { Society }\end{array}$ & US \\
\hline Oxford University Press & Large & $\begin{array}{l}\text { University } \\
\text { Press }\end{array}$ & UK \\
\hline Physicians Postgraduate Press & Small & $\begin{array}{l}\text { University } \\
\text { Press }\end{array}$ & US \\
\hline Portland Press & Small & $\begin{array}{l}\text { Learned } \\
\text { Society }\end{array}$ & UK \\
\hline $\begin{array}{l}\text { Professional Engineering Publishing (Institutional of Mechanical } \\
\text { Engineers) }\end{array}$ & Medium & $\begin{array}{l}\text { Learned } \\
\text { Society }\end{array}$ & UK \\
\hline Resilience Alliance & Small & $\begin{array}{l}\text { Learned } \\
\text { Society }\end{array}$ & Canada \\
\hline Rockefeller University Press & Small & $\begin{array}{l}\text { University } \\
\text { Press }\end{array}$ & US \\
\hline Royal College of General Practitioners & Small & $\begin{array}{l}\text { Learned } \\
\text { Society }\end{array}$ & UK \\
\hline Royal Meteorological Society & Small & $\begin{array}{l}\text { Learned } \\
\text { Society }\end{array}$ & UK \\
\hline Royal Society & Medium & $\begin{array}{l}\text { Learned } \\
\text { Society }\end{array}$ & UK \\
\hline Royal Society of Chemistry & Medium & $\begin{array}{l}\text { Learned } \\
\text { Society }\end{array}$ & UK \\
\hline Royal Society of Medicine & Medium & $\begin{array}{l}\text { Learned } \\
\text { Society }\end{array}$ & UK \\
\hline SAGE Publications (UK and US) & Large & Commercial & Multinational \\
\hline School of Management, University of Bath & Small & $\begin{array}{l}\text { University } \\
\text { Press }\end{array}$ & UK \\
\hline Society for Endocrinology & Small & $\begin{array}{l}\text { Learned } \\
\text { Society }\end{array}$ & UK \\
\hline Society for General Microbiology (later Microbiology Society) & Small & $\begin{array}{l}\text { Learned } \\
\text { Society }\end{array}$ & UK \\
\hline Society for Industrial and Applied Mathematics & Medium & $\begin{array}{l}\text { Learned } \\
\text { Society }\end{array}$ & US \\
\hline Society for In-Vitro Biology & Small & $\begin{array}{l}\text { Learned } \\
\text { Society }\end{array}$ & US \\
\hline Society of Dyers and Colourists & Small & $\begin{array}{l}\text { Learned } \\
\text { Society }\end{array}$ & UK \\
\hline Society of Photo-optical Instrumentation Engineers & Medium & $\begin{array}{l}\text { Learned } \\
\text { Society }\end{array}$ & US \\
\hline Springer Verlag (Germany) & Large & Commercial & Germany \\
\hline Stanford University Law School & Small & $\begin{array}{l}\text { University } \\
\text { Press }\end{array}$ & US \\
\hline Taylor \& Francis & Large & Commercial & Multinational \\
\hline
\end{tabular}


Table 4 continued

\begin{tabular}{|c|c|c|c|}
\hline Publisher name & Size & Type & Country \\
\hline University of California Press & Medium & $\begin{array}{l}\text { University } \\
\text { Press }\end{array}$ & US \\
\hline University of Chicago Press & Medium & $\begin{array}{l}\text { University } \\
\text { Press }\end{array}$ & US \\
\hline Wiley-VCH Verlag Berlin & Large & Commercial & Germany \\
\hline Yale Law School & Small & $\begin{array}{l}\text { University } \\
\text { Press }\end{array}$ & US \\
\hline
\end{tabular}

\section{References}

Archambault, E., et al. (2014). Proportion of open access papers published in Peer-Reviewed Journals at the European and world levels-1996-2013. http://science-metrix.com/en/publications/reports/ proportion-of-open-access-papers-published-in-peer-reviewed-journals-at-the. Accessed Oct 2017.

Baldwin, C. (2004). What do learned societies do with their publishing surpluses? (ALPSP and Blackwell Survey). Worthing: ALPSP.

Bergstrom, C. T., \& Bergstrom, T. C. (2004). The costs and benefits of library site licenses to academic journals. Proceedings of the National Academy of Sciences of the United States of America, 101(3), 897-902.

Björk, B.-C. (2017). Gold, green, and black open access. Learned Publishing, pp. 2016-2018. http://doi. wiley.com/10.1002/leap.1096. Accessed Oct 2017.

Clarke, M. (2015). The changing nature of scale in STM and scholarly publishing. Scholarly Kitchen Blog, p. 25, June 2015. https://scholarlykitchen.sspnet.org/2015/06/25/the-changing-nature-of-scale-in-stmand-scholarly-publishing/.

Clarke, M. (2016). Neither fish nor fowl_ Journal Publishing and the University Press _ The Scholarly Kitchen. Scholarly Kitchen Blog, p. 6, July 2016.

Covey, D. T. (2009). Self-archiving journal articles: A case study of faculty practice and missed opportunity. Portal: Libraries and the Academy, 9, 223-251.

Crow, R. (2006). Publishing cooperatives:analternative for society publishers (SPARC discussion paper). Washington, DC: SPARC.

Finch, J., et al. (2012). Accessibility, sustainability, excellence: how to expand access to research publications. www.researchinfonet. org/wp-content/uploads/2013/02/Final-version.pdf. Accessed Oct 2017.

Fuchs, C., \& Sandoval, M. (2013). The diamond model of open access publishing: Why policy makers, scholars, universities, libraries, labour unions and the publishing world need to take non-commercial, non-profit open access serious. TripleC, 11(2), 428-443.

Fyfe, A., Coate, K., Curry, S., Lawson, S., Moxham, N., \& Rostvik, C. M. (2017). Untangling academic publishing: A history of the relationship between commercial interests, academic prestige and the circulation of research. University of St Andrews, St Andrews. https://doi.org/10.5281/zenodo.546100.

Gadd, E., Oppenheim, C., \& Probets, S. (2003). RoMEO studies 4: An analysis of journal publishers' copyright agreements. Learned Publishing, 16(4), 293-308.

Gadd, E. \& Troll Covey, D. (2016). What does "green" open access mean? Tracking twelve years of changes to publisher self-archiving policies. Journal of Librarianship and Information Science. https:// dspace.lboro.ac.uk/2134/21555. Accessed Oct 2017.

Inger, S., \& Gardner, T. (2013). Scholarly journals publishing practice: academic journal publishers' policies and practices in online publishing. Fourth survey. West Sussex: ALPSP.

Jamali, H. R. (2017). Copyright compliance and infringement in ResearchGate full-text journal articles. Scientometrics, 112(1), 241-254. https://doi.org/10.1007/s11192-017-2291-4.

Johnson, R., et al. (2017). Towards a competitive and sustainable open access publishing market in Europe: A study prepared for the OpenAIRE 2020 project, on behalf of the European Commission. http:// eprints.whiterose.ac.uk/114081/1/OA market report (Final 13 March 2017).pdf. Accessed Oct 2017.

Laakso, M. (2014). Green open access policies of scholarly journal publishers: A study of what, when, and where self-archiving is allowed. Scientometrics, 99, 475-494. 
Laakso, M. \& Björk, B.-C. (2012). Anatomy of open access publishing: a study of longitudinal development and internal structure. BMC Medicine, 10. http://www.scopus.com/inward/record.url?eid=2-s2.084867656894\&partnerID=40\&md5=2a21739c899e4e5f8a12bbf9705a619c. Accessed Oct 2017.

Laakso, M., \& Björk, B. C. (2013). Delayed open access: An Overlooked high-impact category of openly available scientific literature mikael. Journal of the American Society for Information Science and Technology, 64(7), 1323-1329.

Liu, L. G., \& Gee, H. (2017). Determining whether commercial publishers overcharge libraries for scholarly journals in the fields of science, technology, and medicine, with a semilogarithmic econometric model. Library Quarterly, 87(2), 150-172.

Miguel, S. (2011). Open access and scopus: A new approach to scientific visibility from the standpoint of access. Journal of the American Society for Information Science and Technology, 62(6), 1130-1145.

Morris, S. (2007). Mapping the journal publishing landscape: How much do we know? Learned Publishing, 20(4), 299-309.

National Institutes for Health (NIH) (2005). Policy on enhancing public access to archived publications resulting from NIH-funded research (NOT-OD-05-022). https:/grants.nih.gov/grants/guide/noticefiles/NOT-OD-05-022.html. Accessed Oct 2017.

Pinfield, S., Salter, J., \& Bath, P. A. (2015). The "total cost of publication" in a hybrid open-access environment: institutional approaches to funding journal article-processing charges in combination with subscriptions. Journal of the Association for Information Science and Technology, 67(7), 1751-1766.

Pinfield, S., Salter, J., \& Bath, P. A. (2016). A “Gold-centric" implementation of open access: Hybrid journals, the "total cost of publication," and policy development in the UK and beyond. Journal of the Association for Information Science and Technology, 68(9), 2248-2263.

Research Councils UK (2013). Open access. http://www.rcuk.ac.uk/research/openaccess/. Accessed Oct 2017.

Shamash, K. (2016). Article processing charges (APCs) and subscriptions: monitoring open access costs. https://www.jisc.ac.uk/reports/apcs-and-subscriptions. Accessed 9 April 2018.

Speicher, L., 2016. New University Presses. UCL Press Blog, p. 24 Octboer, 2016. https://blogs.ucl.ac.uk/ ucl-press/2016/10/new-university-presses/\#.WIH7S1OLR0w.

Suber, P. (2006). Open access mandates coming to the RCUK. SPARC Open Access Newsletter, 99, July 2 , 2006. http://legacy.earlham.edu/ peters/fos/newsletter/07-02-06.htm\#rcuk.

US Government Office for Science and Technology Policy (2013). Increasing access to the results of federally funded scientific research. February, 2013. https://obamawhitehouse.archives.gov/sites/ default/files/microsites/ostp/ostp_public_access_memo_2013.pdf. Accessed 9 April 2018.

Wakeling, S., Willett, P., Creaser, C., Fry, J., Pinfield, S., \& Spezi, V. (2016). Open access mega-journals: A bibliometric profile. PLoS ONE. https://doi.org/10.1371/journal.pone.0165359.

Ware, M. \& Mabe, M. (2009). The stm report. The STM Report, (November), p. 68. http://www.stm-assoc. org/2009_10_13_MWC_STM_Report.pdf. Accessed Oct 2017.

Ware, M. \& Mabe, M. (2015). The stm report. The STM Report, 4th edition, (September), p. 68. http://www. stm-assoc.org/2009_10_13_MWC_STM_Report.pdf.

Wellcome Trust (2005). Open access policy. https://wellcome.ac.uk/funding/managing-grant/open-accesspolicy. Accessed Oct 2017. 